\title{
Responses of Six Tomato (Lycopersicon esculentum Mill.) Genotypes to Salinity Stress at Low Altitudes of Bengkulu, Indonesia.
}

\author{
Usman K.J. Suharjo ${ }^{1}$, Sartika Y. Nababan ${ }^{2}$, Masdar $^{1}$, T. Pamekas ${ }^{3}$, and Mukhtasar ${ }^{1}$. \\ ${ }^{1}$ Faculty member at the Department of Agronomy, College of Agriculture, University of Bengkulu, Jl. W.R. Supratman, \\ Kandanglimun, Bengkulu, 38371, Indonesia. \\ ${ }^{2}$ Former student at the at the Department of Agronomy, College of Agriculture, University of Bengkulu, Jl. W.R. \\ Supratman, Kandanglimun, Bengkulu, 38371, Indonesia. \\ ${ }^{3}$ Faculty member at the Department of Plant Protection, College of Agriculture, University of Bengkulu, Jl. W.R. \\ Supratman, Kandanglimun, Bengkulu, 38371, Indonesia.
}

\author{
ARTICLE INFO \\ Keywords: \\ tomatoes, salinity stress, LC50 \\ Article history: \\ Received: April 28, 2018 \\ Accepted: June 29, 2018 \\ *Corresponding author: \\ E-mail: usmankris@unib.ac.id
}

\begin{abstract}
Salinity stress causing water deficit, nutrient deficiency, and ion imbalance for the crops has been reported to reduced crop growth, crop yield, and fruit quality in tomatoes. The main objective of this research were to determine the LC-50 of salinity, to evalute the response of six tomato genotypes to LC-50, and to study the effect of genotype and salinity stress on crop growth, crop yield, and fruit quality of tomatoes. The LC-50 of salinity was determinated by growing tomato seedlings at different level of saline solutions $(0,400,500$, $6000,7000,9000,10000,11000$, and $12000 \mathrm{ppm}$ of $\mathrm{NaCl}$ ) and used the LC50 of salinity to evaluate the salinity tolerance of six tomato genotypes. The results showed that the LC-50 of saline solution was $9000 \mathrm{ppm} \mathrm{NaCl}$ and genotype Empat $\mathrm{G}$ was found to be the most tolerant to salinity stress
\end{abstract}

\section{INTRODUCTION}

Tomatoes (Lycopersicon esculentum Mill.) has widely been used as a vegetable, pharmacy, and cosmetics (Wijayanti and Susila, 2013). The national tomato production of Indonesian is considered very low, about 877,801 metric ton in 2015 (BPS, 2016a). The low production is attributed to the pests, low yielding seeds, unfertile soil, and abiotic stress factors, such as salinity (Las et al., 2006). Salinity was reported to reduce tomato production up to $10-50 \%$ in East Nusa Tenggara (Boboy, 2011). Salinity is believed to become one of the most limiting factor in the future, due to the change in percipitation pattern as a result of global warming (Chinnusary et al., 2005).

Salinity is known as a condition in which the concentration of salt, mainly but not limited to $\mathrm{NaCl}$ and $\mathrm{Na}_{2} \mathrm{SO}_{4}$, in a soil solution has electric conductive (EC) no less than $4 \mathrm{dS} / \mathrm{m}$ and exchangeable sodium of 15 ESP or more (Djukri, 2009). Salinity stress takes place due to the following factors: sea water intrussion (Aswidinnoor et al., 2008), lack of percipitation at the area of high evapotranspiration so that no water is enough to dilute the accumulated salt in the soil (Rusd, 2011), natural wheatering of host rock, climatic factros, and fertilizers (Rengasamy, 2006). Salinity stess limits water supply to crops, reduces nutrient uptake, and causes ion toxicity to in the plant cells (Sopandie, 2013). Taufiq and Purwaningsih (2013) reported that salinity stress reduced the number of pod in mungbean up to $37 \%$. In longbean, it reduced the yield up to $40 \%$.

Attempt to solve salinity problems might be done by mitigating the saline soil or by obtaining suitable crop for the salin condition through crop improvement (Sunarto, 2001), such as introduction, hybridization, and selection (Darliah et al, 2010). Selection is done by growing the crops at various saline conditions by which tolerant crops might be obtained. Arnanto et al. (2013) having grown 10 genotypes of $\mathrm{F} 1$ tomatoes in various saline solution $(0,750,1500$, and $2250 \mathrm{mg} / \mathrm{polybag})$ to find which genotype was tolerant to saline solutions reported that all the genotype tested showed no reduction in growth and yield. Higher salt concentrations (2500, 5000 , and $7500 \mathrm{ppm} \mathrm{NaCl}$ ) have been employed by Rahmawati et al. (2012). The results showed that significant growth reduction was found at $7500 \mathrm{ppm}$.

At this current experiment, the authors were selecting 6 tomato genotypes against salinity stress at lethal concentration of 50 (LC-50), at which saline concentration $50 \%$ of tomato crops were unable to finish their life cycle. The objective of this experiment were to determine the LC50 of salinity

ISSN: 1410-3354 / e-ISSN:2615-7136

Cited this as: Suharjo,U.K.J., S.Y. Nababan, Masdar, T. Pamekas, and Mukhtasar. 2018. Responses of six tomato (Lycopersicon esculentum Mill.) genotypes to salinity stress at low altitudes of Bengkulu, Indonesia. Akta Agrosia 21 (1):19- 24 
level for tomato seeedlings, to evaluate the effect of genotype to the growth and yield of tomato crops, to evaluate the effect of salinity to the growth and yield of tomato crops, and to evaluate the interaction effects of genotype and salinity level to the growth and yield of tomato crops.

\section{MATERIALS AND METHODS}

The research was carried out in two experiments at the greenhouse of the Department Agronomy, the University of Bengkulu, $10 \mathrm{~m}$ above sea level, from June 2017 to January 2017. The first experiment was determining the LC50 of salinity level for tomato seedlings. The second experiment was using the LC50 to evaluate the salinity tolerance of 6 tomato genotypes widely grown by Indonesian farmers.

\section{LC50 Experiment}

Tomato seedlings ( 5 each) were grown in the polybag filled with $3 \mathrm{~kg}$ of sterile media, a mixed of cow manure compost and top soil (1:9 by volume). Media sterilization was done by spraying $4 \%$ of formaline solution to the media follwed by tightly covering the media by plastic sheet for 2 weeks. The seedlings were fertilized with NPK (15-15-15) at planting time. Salt solutions (0, 1000, 2000, 3000, 4000, 5000, 6000, 7000, 8000, 9000, 10000, 11000, and $12000 \mathrm{ppm}$ ) were daily poured to the media until it reach field capacity. The number of potato seedlings were evaluated for their mortality. Plynomial orthogonal analysis was used to determinet the LC50 of salinity level. The concentration at which $50 \%$ of the seedlings dead was determinated as the $50 \%$ of salinity. The LC50 was used in the following experiment to evaluate the performance of 5 tomato genotype againts salinity stress.

\section{Salinity Tolerant Experiment}

The experiment was arranged in completely randomized design (CRD) with 2 factors and 5 replications. The first factor tested was tomato genotypes (G), consisting of 6 levels including Kedurang, Empat G, Enam, Itora, Empat, and 22. The second factor tested was salinity level (S), consisting of two levels ( 0 , and $9000 \mathrm{ppm})$.

Tomato seedlings having 5-6 leaf blades were transplanted to a polybag filled with $10 \mathrm{~kg}$ of sterile media, a mixed of cow manures and top soil $(9: 1, \mathrm{v} / \mathrm{v})$. At planting, 0,5 g of carbofuran $3 \mathrm{G}$ were put at each polybag. Right after planting, the media were watered with a mixed of pesticide solutions $(2 \mathrm{~g} / \mathrm{l}$ of streptomysin sulphate $20 \%$ and $2 \mathrm{~g} / 1$ of mankozeb $80 \%$ ). Three days after planting, the crops were fertilized with 100 $\mathrm{kg} / \mathrm{ha}$ of Urea, $100 \mathrm{~kg} / \mathrm{ha}$ of TSP, and $500 \mathrm{~kg} / \mathrm{ha}$ of $\mathrm{KCl}$. The same rate of fertilizers were given at three weeks after transplanting.

Crop protection was done by spraying Deltamethrine (2.5 g/l), Mankozeb 80\% (2 g/l), Streptomysin sulphate 20\% ( 2 g/l) every week. In addition, weed control was manually carried out anytime any weed was spotted.

Salinity treatments were done daily by watering the media with salt solutions $(0,9000 \mathrm{ppm})$ to reach the field capacity level. The treatments were started when the crops were 2 weeks old after transplanting and terminated when the crops reached senescene stage.

The variables measured included plant height (measured weekly from week 1 to week 6 after transplanting), number of leaf (measured weekly from week 1 to week 6 after transplanting), flowering time, number of flower buches, number of flower per buch, number of flower per plant, number of fruit per bunch, number of fruit per plant, harvesting time, fruit diameter, fruit length, average of fruit weight, fruit weight per plants. All data obtained were analized by analysis of variance (ANOVA) followed by Duncan's Multiple Range Test at 5\%.

\section{RESULTS AND DISCUSSIONS}

\section{LD 50}

The polynomial orthogonal analysis showed that the saline concentration at which $50 \%$ tomato seedling died was at $9000 \mathrm{ppm} \mathrm{NaCl}$, as shown in Figure 1. The results of analysis of variance showed that genotypes significantly affected all variables measured except for plant height.

Furthermore, salt solutions significantly affected all variables measured except for flowering age and number of flower per bunch. In addition, the interaction between genotype and salinity was only significantly affected number of flower and fruit per plant, average of fruit wieght, and fruit diameter (Table 1).

\section{Effect of Genotypes}

While Genotype did not significantly affected plant height, it signifantly affected leaf number (Table 2.) with the highest number of leaf was found in Empat G (53,6 blades) and the smallest number was found in Itera (17.3 blades). Plant height and leaf number were two traits that reflected crop growth (Onggo, 2009; Nazirwan et al., 2014) and might be used for screening of tomato genotype for salinity tolerance.

Genotype Kedurang showed the earliest time of flowering (15.08 days) while genotype Empat the latest one (30.75 days). Furthermore, Kedurang produced 24.4 flower bunches whereas Empat only produced 6.91 flower bunches. As they were grown at the same environments, the differences in growth habit was therefore assumed to be attibuted by their genetics (Arnanto et al., 2013; Hidayat, 2003; Sutapraja, 2008). Olaniyi et al. (2010) stated that the genetic composition of tomato plants dictates when and how the tomato plant produce flowers. Furthermore, the number of flower bunch per plant and the number of flower per bunch were expected to affect the number of fruit per buch and the the number of fruit per plant as these traits. It was true this experiment in which the plant producing the highest number of flower bunch and the number of flower per bunch also produced the highest number of fruits (Table 2). In addition, Kedurang was also the earliest genotype to harvest while Itera was the latest, along with genotype Empat, suggesting that the traits were controlled by genetic factor (Sumarno, 1985). In fact, the earliness in flowering and harvesting were 


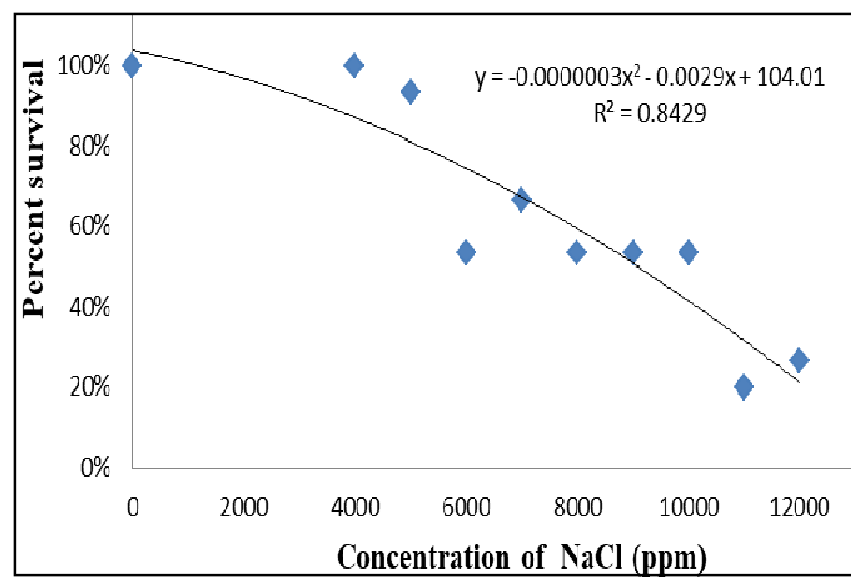

Figure 1. Response of tomato seedlings to salinity stess two traits that could be used as the indicator for genetic superiority of a given tomato genotype (Syukur et al., 2012).

The highest fruit weight was shown by found in genotype Empat (22.02 g) while the lowest was found in genotype Enam (4.32 g). It was not surprising to find this significant differences as genotype Empat, along with Itera, was known as genotype having a large fruits while the rest were known as small-fruit genotypes, suggesting that fruit size was controlled by genetic expression, rather than by environment like fruit number (Sutapradja and Sumarmi, 1996). Along with fruit number, fruit weight (size) determined total fruit weight, as suggested by Syukur et al. (2012).

\section{Effect of Salinity}

In general, salinity treatment (9000 ppm salt) reduced crop growth, crop yield, and fruit quality by $50 \%$, as compared to the control treatment (0 ppm salt), with the exception for time of flowering, number of flower and fruit per bunch, and the diameter and the length of fruit (Table 3). These results confirming the LC50 experiment at which about $50 \%$ of tomato seedlings were dead when exposed to 9000 ppm of

Table 1. Result of variance analysis

\begin{tabular}{lcccc}
\hline & \multicolumn{5}{c}{ Calculated F value } \\
Variable measured & \multicolumn{2}{c}{ Genotype } & NaCl & Interaction \\
\hline Plant height & $0.44 \mathrm{~ns}$ & $39.05 * *$ & $1.75 \mathrm{~ns}$ & 13.88 \\
Number of leaf & $7.27 * *$ & $24.83 * *$ & $1.00 \mathrm{~ns}$ & 17.11 \\
Flowering age & $11.98 * *$ & $33.32 * *$ & $1.47 \mathrm{~ns}$ & 19.40 \\
Number of flower bunch & $8.54 * *$ & $2.38 * *$ & $1.30 \mathrm{~ns}$ & 20.45 \\
Number of fruit per bunch & $46.13 * *$ & $7.29 *$ & $1.11 \mathrm{~ns}$ & 11.64 \\
Number of flower per plant & $21.69 * *$ & $43.67 * *$ & $2.66 *$ & 12.35 \\
Number of fruit per plant & $37.61 * *$ & $39.93 * *$ & $2.94 *$ & 15.57 \\
Harvesting time & $5.61 * *$ & $5.82 *$ & $2.20 \mathrm{~ns}$ & 14.30 \\
Average fruit weight & $81.86 * *$ & $90.04 * *$ & $8.79 * *$ & 8.90 \\
Fruit diameter & $69.24 * *$ & $77.26 * *$ & $3.96 * *$ & 8.60 \\
Fruit length & $16.07 * *$ & $19.97 * *$ & $2.56 \mathrm{~ns}$ & 10.11 \\
Fruit weight per plant & $4.71 * *$ & $94.72 * *$ & $2.41 \mathrm{~ns}$ & 16.92 \\
\hline
\end{tabular}

Note: *significantly different at $5 \% ; * *$ siqnificantly different at $1 \%$; ns: non significantly different.

Table 2. The effects of genotypes on crop growth, crop yield, and fruit quality.

\begin{tabular}{lrrrrrr}
\hline & \multicolumn{7}{c}{ Tomato genotypes } \\
\cline { 2 - 7 } \multicolumn{1}{c}{ Variable measured } & Kedurang & Empat G & Enam & Itera & Empat & 22 \\
\hline Plant height (cm) & $81.8 \mathrm{a}$ & $73.8 \mathrm{a}$ & $74.4 \mathrm{a}$ & $78.3 \mathrm{a}$ & $77.3 \mathrm{a}$ & $76.6 \mathrm{a}$ \\
Leaf number (blades) & $53.2 \mathrm{a}$ & $53.6 \mathrm{a}$ & $45.0 \mathrm{ab}$ & $17.3 \mathrm{a}$ & $30.03 \mathrm{bc}$ & $32.5 \mathrm{abc}$ \\
Age of flowering (day) & $15.1 \mathrm{c}$ & $16.0 \mathrm{c}$ & $17.3 \mathrm{c}$ & $25.2 \mathrm{~b}$ & $30.8 \mathrm{a}$ & $23.8 \mathrm{~b}$ \\
\# of flower bunch & $24.4 \mathrm{a}$ & $24.8 \mathrm{a}$ & $28,2 \mathrm{a}$ & $6.4 \mathrm{~b}$ & $6.9 \mathrm{~b}$ & $22.0 \mathrm{a}$ \\
\# of flower per bunch & $6.2 \mathrm{~b}$ & $7.2 \mathrm{a}$ & $6.3 \mathrm{ab}$ & $6.7 \mathrm{ab}$ & $4.7 \mathrm{c}$ & $6.9 \mathrm{ab}$ \\
\# of fruit per bunch & $6.0 \mathrm{a}$ & $6.7 \mathrm{a}$ & $6.1 \mathrm{a}$ & $4.7 \mathrm{~b}$ & $1.9 \mathrm{c}$ & $6.4 \mathrm{a}$ \\
\# of flower per plant & $99.9 \mathrm{a}$ & $122.7 \mathrm{a}$ & $113.1 \mathrm{a}$ & $37.8 \mathrm{~b}$ & $23.0 \mathrm{~b}$ & $107.7 \mathrm{a}$ \\
\# of fruit per plant & $85.5 \mathrm{ab}$ & $108.0 \mathrm{a}$ & $93.3 \mathrm{ab}$ & $23.4 \mathrm{c}$ & $12.7 \mathrm{c}$ & $78.0 \mathrm{~b}$ \\
Harversting time (day) & $39.3 \mathrm{c}$ & $42.2 \mathrm{c}$ & $43.8 \mathrm{bc}$ & $49.2 \mathrm{a}$ & $47.3 \mathrm{ab}$ & $48.3 \mathrm{ab}$ \\
Average of fruit weight (g) & $6.5 \mathrm{c}$ & $5.2 \mathrm{c}$ & $4.3 \mathrm{c}$ & $14.7 \mathrm{~b}$ & $33.3 \mathrm{a}$ & $5.1 \mathrm{c}$ \\
Fruit diameter (mm) & $22.3 \mathrm{c}$ & $20.9 \mathrm{~cd}$ & $19.7 \mathrm{~d}$ & $27.6 \mathrm{~b}$ & $33.3 \mathrm{a}$ & $21.0 \mathrm{~b}$ \\
Fruit length (mm) & $21.8 \mathrm{~b}$ & $20.3 \mathrm{~b}$ & $20.6 \mathrm{~b}$ & $28.2 \mathrm{a}$ & $27.9 \mathrm{a}$ & $20.1 \mathrm{~b}$ \\
Fruit weight per plant (g) & $471.1 \mathrm{a}$ & $477.3 \mathrm{a}$ & $358.8 \mathrm{a}$ & $347.8 \mathrm{a}$ & $220.6 \mathrm{~b}$ & $431.6 \mathrm{a}$ \\
\hline
\end{tabular}

Note: the number at the same line followed by the same letter were non-significantly different at $5 \%$ of DMRT. 
salt solutions. Reducing crop growth and crops yield when the crops exposed to salinity stress, has previously been reported for soybean (Sunarto, 2001), peanut by Taufik et al. (2015), and tomatoes (Boboy, 2011; Rahmawati et al., 2012; Arnanto et al., 2015; Wulandari, 2016). Reducing crop growth was likely caused by the increase in $\mathrm{Na}^{+}$in the cell which in turn disturbed the ion balance between $\mathrm{Na}^{+}$and $\mathrm{K}^{+}$as well as between $\mathrm{Na}^{+}$and $\mathrm{Ca}^{2+}$. As salinility level in the soil solution increases, $\mathrm{Na}^{+}$uptake by root also increases. However, it significantly reduces the uptake of $\mathrm{K}^{+}$ and $\mathrm{Ca}^{2+}$ (Summart, 2010). While $\mathrm{K}^{+}$has significant role in the opening and closing of leaf stomates, $\mathrm{Ca}^{2+}$ take direct part in the cell wall formation (Salisbury and Ross, 1998). Therefore, when exposed to salin environment, crops will undergo osmotical stress, leading to the delay in leaf emergence, reduce in leaf area, and promoting leaf senescence, as a result of the accumulation of toxic ions (Rajendra et al., 2009). Furthermore, increasing salt level in the soil solution reduces the water potential of soil solution, which lead to the increase in energy spent by the crops to access water and nutrition as well as to maintain the cell turgor. As a consequence, water and nutrition uptake will reduce significantly when crops do not have enough energy sources, resulting in the reduction in crop growth and crop yield (Sopandie, 2013). These findings confirmed what Darwish et al. (2009) has reported.

Salinity treatment did not sginificantly affect the age of flowering time and the number of flower per bunch even though it significantly reduced the number of flower bunch, the number of fruit per bunch, and the number of fruit per plant. Duman (2012) stated that it might be caused by the limited P uptake, as a result of the increase in osmotic potential of the soil solutions, which led to the to flowering inhibition and fruit initiation (Harjadi and Yahya, 1988). Similar results have been reported by Taufiq and Purwaningsih (2013) for mungbean, in which they found that salinity treatments reduced the number of pod per plant and the weight of 100 grains.

Salinity treatments also significantly reduced fruit quality, such as fruit weight, fruit diameter, and fruit length although it promoted harvesting time. These findings were confirming the results of previous experiment reported by Boboy (2012) and Rahmati et al (2012), finding that salinity stress reduced the number of fruit, the weight of fruit, the diameter of fruit, and length of fruit.

\section{Interaction between Genotype and Salinity}

The interaction between genotype and salinity significantly number of flower, number of fruit, average of fruit weight, and fruit diameter. Itera and Empat showed no differences in the number of flower per plant when grown at $0 \mathrm{ppm}$ and $9000 \mathrm{ppm} \mathrm{NaCl}$. On the other hand, Empat G showed nearly $40 \%$ of reduction in flower number at $9000 \mathrm{ppm} \mathrm{NaCl}$ even though the figure was still the highest among the treatments (67.7 flowers). It was contradict to the previous results reported by Rahmawati (2011) finding that at $7500 \mathrm{ppm} \mathrm{NaCl}$ did not reduce the number of flowers per plant. The differences in flower number may be caused by the differences in genotypes or by environemental factors, such as nutrition deficiency especially $\mathrm{P}$ which delay flower initiation (Wijaya, 2008).

Table 3. The effects of salinity on crop growth, crop yield, and fruit quality.

\begin{tabular}{lrr}
\hline \multirow{2}{*}{ Variables measured } & \multicolumn{2}{c}{$\mathrm{NaCl}(\mathrm{ppm})$} \\
\cline { 2 - 3 } & \multicolumn{1}{c}{0} & 9000 \\
\hline Plant height (cm) & $50.1 \mathrm{a}$ & $65.9 \mathrm{~b}$ \\
\# of leaf (blades) & $21.1 \mathrm{a}$ & $21.5 \mathrm{a}$ \\
Age of flowering (day) & $26.3 \mathrm{a}$ & $11.3 \mathrm{~b}$ \\
\# of flower bunch & $6.5 \mathrm{a}$ & $6.1 \mathrm{a}$ \\
\# of flower per bunch & $5.6 \mathrm{a}$ & $5.0 \mathrm{~b}$ \\
\# of fruit per bunch & $113.6 \mathrm{a}$ & $54.4 \mathrm{~b}$ \\
\# of flower per plant & $87.6 \mathrm{a}$ & $46.0 \mathrm{~b}$ \\
\# of fruit per plant & $46.6 \mathrm{a}$ & $43.4 \mathrm{~b}$ \\
Harvesting time (day) & $12.7 \mathrm{a}$ & $6.7 \mathrm{~b}$ \\
Average of fruit weight (g) & $26.4 \mathrm{a}$ & $21.9 \mathrm{~b}$ \\
Fruit diameter (mm) & $25.1 \mathrm{a}$ & $21.1 \mathrm{~b}$ \\
Fruit length (mm) & $580.2 \mathrm{a}$ & $189.2 \mathrm{~b}$ \\
Total fruit weight (g) &
\end{tabular}

Note: the number at the same column followed by the same letter were non-significantly different at $5 \%$ of DMRT.

Without salinity treatment ( 0 ppm $\mathrm{NaCl})$, genotype Itera and Empat showed very small number of fruit per plant, which were less than 30 fruits while the rest of the genotypes produced 114 to 128 fruits (Tablel). Farthermore, at $9000 \mathrm{ppm} \mathrm{NaCl}$, Itera and Empat showed the least reduction in fruit number $(<28 \%)$. However, both genotypes produced the least number of fruit at $9000 \mathrm{ppm} \mathrm{NaCl}$. On the other hand, even though Empat G lost nearly 30\% of the fruits at $9000 \mathrm{ppm}$, it produced the highest number of fruit (88 fruits). These findings suggested that both genotype and salinity did not worked indpendently in affecting fruit numberm, as suggested by Suryadi et al. (2004) and Wiguna and Sumpena (2012).

Genotype Empat $G$ and Empat were the only genotypes that did not show reduction in fruit diameter whether they were exposed to salinity stress $(9000 \mathrm{ppm} \mathrm{NaCl})$ or not $(0 \mathrm{ppm} \mathrm{NaCl})$. The rest of the genotypes, on the other hand, showed significant reduction in fruit diameter with the lowest reduction found in genotype Empat G (Table 4). At 9000 ppm $\mathrm{NaCl}$, the highest fruit diameter was found in genotype Empat $(30,57 \mathrm{~mm})$ while the lowest diameter was found in genotype $22(18.97 \mathrm{~mm})$. These findings confirmed the previous results reported by Chookhampaen et al. (2008) and Rahmawati (2016) in which fruit dimater and fruit weight significantly reduced as the salinity livel increased.

Genotype Empat showed the highest fruit weight when grown either without $(0 \mathrm{ppm} \mathrm{NaCl})$ or with $(9000 \mathrm{ppm} \mathrm{NaCl})$ salinity stress although there was a significant reduction (about 48\%) in fruit diamater (from $28.9 \mathrm{~mm}$ to $15,2 \mathrm{~mm}$ ). It might be because this genotype was one of the genotype producing large fruit. In fact, the fruit diameter of genotype Empat at 9000 
Table 4. Effect of genotype and $\mathrm{NaCl}$ interaction on the number of flower per plant

\begin{tabular}{lcc}
\hline \multirow{2}{*}{ Genotype } & \multicolumn{2}{c}{$\mathrm{NaCl}(\mathrm{ppm})$} \\
\cline { 2 - 3 } & $134.02 \mathrm{a}$ & 9000 \\
\hline Kedurang & $(\mathrm{A})$ & $65.83 \mathrm{ab}$ \\
\multirow{2}{*}{ Empat $\mathrm{G}$} & $151.01 \mathrm{a}$ & $93.33 \mathrm{a}$ \\
& $(\mathrm{A})$ & $(\mathrm{B})$ \\
Enam & $158.52 \mathrm{a}$ & $67.66 \mathrm{ab}$ \\
& $(\mathrm{A})$ & $(\mathrm{B})$ \\
Itera & $47.66 \mathrm{~b}$ & $28.02 \mathrm{c}$ \\
& $(\mathrm{A})$ & $(\mathrm{A})$ \\
Empat & $26.33 \mathrm{~b}$ & $19.83 \mathrm{c}$ \\
& $(\mathrm{A})$ & $(\mathrm{A})$ \\
22 & $164.33 \mathrm{a}$ & $51.12 \mathrm{bc}$ \\
& $(\mathrm{A})$ & $(\mathrm{B})$ \\
\hline
\end{tabular}

ppm $\mathrm{NaCl}$ was higher than those of almost all genotypes tested (Table 5). The lowest reduction in fruit diameter was found in genotype Empat G (18\%).

Widarmi (2011) stated that when the effect of interaction between genotype and environment is significant, an ideal genotype to be grown at that situation is the one having the highest yield. In our case, genotype Empat $\mathrm{G}$ was the genotype having the highest yield at $9000 \mathrm{ppm} \mathrm{NaCl}$ (Table 6). It is therefore the authors recommended that genotype Empat $\mathrm{G}$ be grown at salin soil because was able to maintin the high yield when exposed to high salinity stress $(9000 \mathrm{ppm} \mathrm{NaCl})$.

Table 5. Effect of genotype and $\mathrm{NaCl}$ interaction on the number of fruits per plant

\begin{tabular}{lcc}
\hline \multirow{2}{*}{ Genotype } & \multicolumn{2}{c}{$\mathrm{NaCl}(\mathrm{ppm})$} \\
\cline { 2 - 3 } & 0 & 9000 \\
\hline Kedurang & $117.5 \mathrm{a}$ & $53.5 \mathrm{~b}$ \\
& $(\mathrm{~A})$ & $(\mathrm{B})$ \\
Empat $\mathrm{G}$ & $126.2 \mathrm{a}$ & $88.2 \mathrm{a}$ \\
& $(\mathrm{A})$ & $(\mathrm{B})$ \\
Enam & $124.7 \mathrm{a}$ & $61.8 \mathrm{~b}$ \\
& $(\mathrm{~A})$ & $(\mathrm{B})$ \\
Itera & $27.2 \mathrm{~b}$ & $19.8 \mathrm{c}$ \\
& $(\mathrm{A})$ & $(\mathrm{A})$ \\
Empat & $14.3 \mathrm{~b}$ & $11.2 \mathrm{c}$ \\
& $(\mathrm{A})$ & $(\mathrm{A})$ \\
22 & $114.2 \mathrm{a}$ & $41.8 \mathrm{bc}$ \\
& $(\mathrm{A})$ & $(\mathrm{B})$ \\
\hline
\end{tabular}

\section{CONCLUSSIONS}

Salt concentration that caused $50 \%$ of tomato seedlings died (LC-50) was $9000 \mathrm{ppm} \mathrm{NaCl}$. It significantly reduced crop growth, crop yield, and fruit quality of 6 potato genotypes. The tomato genotype showing the best growth and yield was Empat G. When exposed to LC-50 salinity levels, genotype Empat $\mathrm{G}$ showed the best growth and yield. It was therefore recommended that $9000 \mathrm{ppm}$ salinity level (LC-50) be used for screening tomato genotypes for salinity tolerance.

\section{REFERENCES}

Amor, D. M. F., V. Martinez., A, Cerda. 2001. Salt Tolerance of Tomato Plants as affected by stage of Plant Development. J. Hortscience. 36 (7):1260-1263.

Ardiyansah., N. D., Alnopri., H.E.Saputra., 2017. Analisis Korelasi, Keragaman Genetik dan Heritabilitas Populasi F2 Hasil Persilangan Tomat TI 1 x TI 84 Pada Dataran Rendah. Skripsi. Fakultas Pertanian Universitas Bengkulu. Bengkulu. (Tidak Dipublikasikan).

Arnanto. D., N. Basuki., Respatijarti., 2013. Uji Toleransi Salinitas terhadap Sepuluh Genotipe F1 Tomat (Solanum lycopersicum L). J. Produksi Tanaman 1 (5) : $415: 421$.

Aswidinnoor, H., M. Sabran., Masganti., Susilawati. 2008. Perakitan Varietas Unggul Padi Tipe Baru dan Padi Tipe Baru Ratun Apesifik Lahan Pasang Surut Kalimantan untuk Mendukung Teknologi Budidaya Dua Kali Panen Setahun. Laporan Hasil Penelitian KKP3T. Institut Pertanian Bogor.

Badan Pusat Statistik (BPS). 2016. Produksi tomat di Bengkulu tahun 2011-2015. https://www. bps.go.id/site/resultTab. Diakses 21 April 2016.

Badan Pusat Statistik (BPS). 2016. Produksi tomat di Indonesia tahun 2015. https://www.bps.go.id/ site/resultTab. Diakses 21 April 2016.

Boboy. W. 2011. Pertumbuhan dan Hasil Tiga Tanaman Tomat Pada Cekaman Salinitas. J. Partner 19 (2) : 92-101.

Chinnusamy, V., A. Jagendorf. J. K. Zhu. 2005. Understand and Improving Salt Tolerance in Plants. Crop Sci. 45 : 437-448.

Chookhampaeng, S., W. Pattanagul, and P. Threerakulpisut. 2008. Effects of salinity on growth, activity of antioxidant enzymes and sucrose content in tomato (Lycopersicum esculentum Mill.) at the reproductive stage. Science Asia. 34: 069 - 075.

Darliah., D. Kurniasih., W. Handayati. 2010. Persilangan dan Seleksi untuk mendapatkan Varietas Unggul Baru Mawar Potong Berwarna Merah. J. Horti 20 (2) : 103-110.

Darwish, E., C. Testerink., M. Khalil., O. El-Shihy., T. Munnik. 2009. Phospholipid signaling

Table 6. Effect of genotype and $\mathrm{NaCl}$ interaction on the average weight of fruit $(\mathrm{g})$

\begin{tabular}{lcc}
\hline \multirow{2}{*}{ Genotype } & \multicolumn{2}{c}{$\mathrm{NaCl}(\mathrm{ppm})$} \\
\cline { 2 - 3 } & 0 & 9000 \\
\hline Kedurang & $7.76 \mathrm{c}$ & $5.25 \mathrm{~b}$ \\
\multirow{3}{*}{ Empat G } & $(\mathrm{A})$ & $(\mathrm{A})$ \\
& $5.97 \mathrm{c}$ & $4.34 \mathrm{~b}$ \\
Enam & $(\mathrm{A})$ & $(\mathrm{A})$ \\
& $5.31 \mathrm{c}$ & $3.34 \mathrm{~b}$ \\
Itera & $(\mathrm{A})$ & $(\mathrm{A})$ \\
& $21.95 \mathrm{a}$ & $7.51 \mathrm{~b}$ \\
Empat & $(\mathrm{A})$ & $(\mathrm{B})$ \\
& $28.9 \mathrm{a}$ & $15.17 \mathrm{a}$ \\
22 & $(\mathrm{~A})$ & $(\mathrm{B})$ \\
& $6.37 \mathrm{c}$ & $3.79 \mathrm{~b}$ \\
& $(\mathrm{~A})$ & $(\mathrm{A})$ \\
\hline
\end{tabular}


responses in salt-stressed rice leaves. Plant Cell Physiol. 50(5):986-997.

Djukri. 2009. Cekaman Salinitas terhadap Pertumbuhan Tanaman. Prosiding Seminar Nasional Penelitian, Pendidikan MIPA, Fakultas MIPA, Universitas Yogyakarta.

Duman, F. 2012. Uptake of mineral Elements During Abiotic Stress. P. Ahmad and M.N.V. Prasad (eds.), Abiotic Stress Responses in Plants: Metabolism, Productivity and Sustainability, Hal 268-276

Ganefianti, D.W., T.Pamekas., Alnopri., Hasanuddin., 2006. Uji Daya Hasil Pendahuluan Galu-Galur Cabai Hasil Persilangan Talang Semut/Tit. Super. Hasil Penelitian Hibah Bersaing. Fakultas Pertanian Universitas Bengkulu: Bengkulu.

Giannakoula, A. E. and I. F. Ilias. 2013. The Effect Of Water Stress And Salinity On Growth And Physiology Of Tomato (Lycopersicon esculentum Mill.) Arch. Biol. Sci. 65(2):611-620.

Gomez, K.a., dan A.A. Gomez. 2010. Prosedur Statistik untuk Penelitian Pertanian Edisi Kedua. Terjemahan dari; Statistical Procedures for Agricultural Research. Peneremah: E. Sjamsudin dan J.S. Baharsah.UI-Press. Jakarta.

Harjadi, S.S dan S. Yahya. 1988. Fisiologi Stress Lingkungan. PAU Bioteknlogi IPB. Bogor.

Hidayat. 2003. Varians dan Kovarians Genetik Sifat Hasil dan Komponen Hasil Tomat. Jurnal Akta Agrosia 6 (1): 7-11.

Karan R, Subudhi P. K. 2012. Approaches to increasing salt tolerance in crop plants. Di dalam: Ahmad P, Prasad MNV, editor. Abiotic Stress Responses in Plant: Metabolism, Productivity and Sustainability. New York(US): Springer.

Kementan. 2016. Luas Panen, Produksi dan Produktivitas Subsektor Hortikultura. http:// www.pertanian.go.id/ap pages/mod/datahorti. Diakses pada tanggal 9 Januari 2017.

Las, I., K. Subagyono, dan A. P Setiyanto. 2006. Isu dan pengelolaan lingkungan dalam revitalisasi pertanian. Jurnal Litbang Pertanian, 25(3):106-115.

Nazirwan, Wahyudi. A., Dulbari. 2014. Karakterisasi Koleksi Plasma Nutfah Tomat Lokal dan Introduksi. J. Penelitian Terapan. 14 (1): 70-75.

Olaniyi, J. O., W. B. Akanbi, T. A. Adejumo and O. G. Akande. 2010. Growth, fruit yield and nutritional quality of tomato varieties. African Journal of Food Science 4(6): 398 - 402.

Onggo, T. M. 2009. Pertumbuhan dan Hasil Tanaman Tomat pada Aplikasi Berbagai Formula dan Dosis Pupuk Organik Majemuk Lengkap. http:// pustaka.unpad.ac.id/wpcontent/uploads/2009/11/ pertumbuhan dan hasil tanaman tomat.pdf. Diakses 5 Februari 2017.

Rachman, A., I. G. M. Subiksa, D. Erfandi, and P. Slavich. 2008. Dynamics of tsunami-affected soil properties. $\mathrm{P}$ 51-64. In F. Agus and G. Tinning (eds). Proc. of Inter. Workshop on Post Tsunami Soil Management.

Rahmawati, H., E. Sulistyaningsih., E.T.S.Putra. 2012. Pengaruh Kadar $\mathrm{NaCl}$ terhadap Hasil dan
Mutu Buah Tomat (Lycopersicum esculentum Mill). Vegetalika 1 (4) : 44-54.

Rajendran, K., M. Tester., S.J. Roy. 2009. Quantifying the three main components of salinity tolerance in cereals. Plant, Cell and Env. 32:237- 249.

Rengasamy, P. 2006, World salinization with emphasis on Austrialia. J. Expt. Bot. 57(1): 1017-1023.

Sopandie, D, 2013. Fisiologi Adaptasi Tanaman terhadap Cekaman Abiotik pada Agroekosistem Tropika. IPB Press : Bogor.

Sprogue. B. J. 1969. Measurement of Pollutant Toxicity To Fish I. Bioasay Methods For Acute Toxicity. Water Research Pergamon Press. 3. 793-821.

Sumarno. 1985. Identifikasi dan Pemanfaatan Kultivar Tomat di Dataran Tinggi atau Rendah. Penerbit Swadaya. Jakarta.

Summart J., Thanonkeo P., Panichajakul S., Prathepha P. and McManus M. T. (2010). "Effect of salt stress on growth, inorganic ion and proline accumulation in Thai aromatic rice, Khao Dawk Mali 105, callus culture". African Journal of Biotechnology. Vol. 9 (2) : 145- 152.

Sunarto. 2001. Toleransi kedelai terhadap tanah salin. Bul. Agron. 29 (1) : 27-30.

Suryadi, Luthfy, K. Yenni, dan Gunawan. 2004. Karakterisasi Koleksi Plasma Nutfah Tomat Lokal dan Introduksi. Buletin Plasma Nutfah 10 (2): 72-76.

Sutapradja, H. dan N. Sumarni. 1996. Pengaruh Dosis Pengapuran dan Kombinasi Pupuk $\mathrm{N}$ dan $\mathrm{P}$ terhadap pertumbuhan dan hasil tomat. J. Hort. (3):263-268.

Syukur, M., S. Sujiprihati, R.Yuniati. 2012. Teknik Pemuliaan Tanamam. Penebar Swadaya. Depok.

Taufiq, A, R. D. Purwaningrahayu. 2013. Tanggap Varietas Kacang Hijau terhadap Cekaman Salinitas. Penelitian Pertanian Tanaman Pangan. 32 (3) : $159-170$.

Taufiq. A., A.Kristiono., D.Harnowo., 2015. Respon Varietas Unggul Kacang Tanah Terhadap Cekaman Salinitas. Penelitian Pertanian Tanaman Pangan. 34 (2) : 153-164.

Wiguna, G., dan U. Sumpena. 2012. Daya Hasil dan Kualitas Benih Enam Kultivar Tomat. Jurnal Pembangunan Pedesaan. 12 (2): 80 - 85.

Wijaya, K.A. 2008. Nutrisi Tanaman Sebagai Penentu Kualitas Hasil Dan Resistensi Alami Tanaman. Prestasi Pustaka Publisher. Jakarta.

Wijayanti, E dan D.A. Susila. 2013. Pertumbuhan dan Produksi Dua Varietas Tomat (Lycopersicum esculentum Mill.) Secara Hidroponik dengan beberapa komposisi media tanam. Buletin Agrohorti 1 (1) 104-112.

Wulanjanri, D. 2016. Pengaruh Pupuk Daun Silika dan Cekaman $\mathrm{NaCl}$ terhadap Pertumbuhan, Produksi, dan Kualitas Tomat (Lycopersicum esculentum Mill) Pada Media Hidroponik Substrat. Tesis. Program Studi Magister Agronomi. Universitas Jember. 